\title{
Organizational structure of transforming League of Communists of Serbia (Part II)
}

\section{Lukáš VOMLELA}

\author{
Ústav středoevropských studií, Fakulta veřejných politik, Slezská univerzita v Opavě \\ Institute of Central-European Studies, Faculty of Public Policies, Silesian University in Opava, \\ Hradecká 665/17, 74601 Opava, Czech Republic \\ lukas.vomlela@fvp.slu.cz
}

\section{Ethnic homogeneity within the party}

In the process of transition, the party members could hold different opinions. The status quo among individual national groups was consistently watched in the parties. The more equal the representation of members of different national groups in the top party bodies, the more probable conflict was among them in changing conditions. Such conflicts were able to affect the work of local party cells also at local level. The ethnic composition of the party and the allotment of key offices according to a specific principle of national parity influenced the transforming ability of the respective League of Communists substantially. In ethnically heterogeneous leagues of communists, certain parity in representation of individual nations and national groups was watched among local communist elites; its considerable violation could endanger considerably the work of the respective local league of communists and contribute very substantially to the disintegration of the republic party organization very substantially. Such situation applied particularly to multi-ethnical Bosnia and Herzegovina and, at lower degree, to Croatia. In Bosnia and Herzegovina, the Bosnian Serbs constituted $47.4 \%$ of local party officials and officials of socio-political organizations (while, according to the census, they constituted $37.3 \%$ of population); the Moslems $29.9 \%$ (constituting $39.6 \%$ of $\mathrm{BiH}$ population); and Bosnian Croats $14.1 \%$ (constituting $20.6 \%$ of population). The representation in legislation bodies and among governmental officials was similar: $43.3 \%$ fell on Bosnian Serbs, $30.4 \%$ on Moslems, and 15.9\% on Bosnian Croats. In top managerial positions, there were $37.5 \%$ Serbs, $19.7 \%$ Croats and $31.1 \%$ Moslems. $^{1}$ In Croatia, the prevailing Croats (79.4\% of population in 1971) were insufficiently represented at the positions of party and republic elites. Among the party and republic elites, they had approximately $71.8 \%$ and $71.9 \%$ representatives, respectively, while they had higher representation in managerial offices (79.3\%). ${ }^{2}$ The Croatian Serbs, constituting $14.2 \%$ of population in the 1970 s, were represented by $21 \%$ among party officials and by $21.5 \%$ among republic elites. As for managerial offices, they were represented insufficiently, constituting $11.7 \%$ of the elites. ${ }^{3}$ The differences in representation at the level of the republic and of top party offices and similar offices in socio-political organizations can be found on

1 COHEN, The Socialist Pyramid, 304.

2 Ibidem, 303.

3 lbidem. 
one hand in managerial positions and on the other hand must be sought in socio-economic differences within the republic. The region where Serbs prevailed ranked among the most underdeveloped parts of Croatia where not much working opportunities had been created, as compared to the other parts of the republic.

The ethnic heterogeneity of the league of communists made difficult the enforcement of changes as well. To support them, acceptance must be sought among representatives of all national groups within the local league of communists, with higher need to consider opinion minorities, in case they got strong support among representatives of one nation. In the process of transition, the ethnic heterogeneity made it very difficult for those leagues of communists to transform. The elites of Bosnia and Herzegovina were watching each other permanently; displays of nationalism were perceived by the leaders of the Bosnian and Herzegovinian League of Communists as threat to the very coexistence within the republic. Any essential changes in the direction of the party required consensus among members in multi-ethnically heterogeneous parties. Without it, disintegration was imminent.

As compared to the other leagues of communists, the League of communists of Serbia was a party including the communists of Vojvodina and Kosovo who had the opportunity to intervene in the development of the League of Communists of Serbia, as it was explained above. At the beginning, Slobodan Milošević needed support of the party elites of Vojvodina and Kosovo, making use of it during the power changes in 1987. One year later, after Slobodan Milošević had come to terms with internal opposition in proper Serbia, he could resolve to intervene against the leaders of the League of Communists of Kosovo and of the League of Communists of Vojvodina whose representatives could not endanger his position during mutual power conflict without strong support of leagues outside the Republic of Serbia. The representatives of both autonomous provinces had minority representation in the common party, in the League of Communists of Serbia, and without finding support of some members of the League of Communists of Serbia, active in the party on behalf of proper Serbia, they could not intervene to Slobodan Milošević' disadvantage. The ethnic composition of the party in proper Serbia was not too heterogeneous; in the process of transformation of the League of Communists of Serbia, the leaders of local communists relied mainly upon the support of party elites in proper Serbia. The ethnic homogeneity of the party members in proper Serbia and the actual control of both autonomous provinces allowed faster transformation of the whole League of Communists of Serbia.

\section{Charismatic leaders}

As it was stated above, the parties that relied only upon the charisma of their top representative were not able to compete with the other parties in the long term. Nevertheless, such factor was able to attract a part of voters, which constitutes a key factor particularly in the first election. Nebojša Vladisavljević evaluated Milošević position at the beginning of 1987 as relatively week, stating that: „without a new programme persuasive to high party officials or the population at large, Milošević would not have been able to change power relations in the higher party echelons and purge powerful rivals from leadership. ${ }^{4}$ Even

4 VLADISAVLJEVIĆ, 52. 
at the beginning of the year, Slobodan Milošević was a rather indistinctive politician who was not able to attract higher attention of the public. According to a public opinion poll performed by NIN weekly magazine, Milošević appealed to only $5 \%$ of the Serbian public. ${ }^{5}$ Slobodan Milošević got particularly strong support during so called Anti-bureaucratic revolution when he succeeded to combine two very strong demands coming from the lower tiers of the society. The national demands, voiced by the Kosovo Serbs, but also by some opposition circles, and the social demands presented in worker strikes and demonstrations. Milošević succeeded to connect to such protest groups and to shield some of them organizationally. The protest events, presented in the course of so called Anti-bureaucratic revolution, constituted combination of protests organized from above and from below. Vidoslav Stevanović points out the fact that the Anti-bureaucratic revolution did not have too strong ideological charge. According to him, it was rather personal then ideological, aiming to eliminate bureaucrats, who opposed him, from different offices and to substitute them by loyal people. ${ }^{6}$ Milošević did not push through (except for restriction of autonomous provinces and centralization of the Republic of Serbia) essential system changes within the autonomous socialism. Additionally, the plan of reintegration of the Republic of Serbia had not been created by Slobodan Milošević, but its enforcement had been unsuccessfully attempted by Milošević' predecessors, his later political opponents Draža Marković, Petar Stambolić, or his nephew Ivan Stambolić.

The national demands were less important to the protesters because the main reason of their protest consisted in their own uncheerful economic situation and they required cure particularly in this field. Jasna Dragović-Soso states that in the course of the unrest, the most protesters considered particularly the economic demands the most important, perceiving the nationalistic demands, related mainly to the situation in Kosovo, as secondary. ${ }^{7}$ Nevertheless, at that time, also nationalistic meetings occurred, organized by Milošević supporters. In that regard, the Committee for participation of Kosovo Serbs was very active; so called meetings of truth were organized in that connection. Thanks to the meetings, Slobodan Milošević arranged for favour and popularity among most inhabitants of Serbia in already the course of $1988 .{ }^{8}$

According to Sabrina Ramet, between 9 July and 4 September 1988, during the auspices of the Committee for protection of Kosovo Serbs and Montenegrins, there were protests in which 160,000 demonstrators participated, and before spring 1989, about 5,000,000 people had participated in the protests, which means that about 50,000 protesters participated in each demonstration on average. ${ }^{9}$ According to Slobodan Antonić, 59 so called meetings of truth took place only in big towns of proper Serbia in summer and in autumn 1988. The towns of Užice, Valjevo, Zaječar, Šabac, Kruševac, Kraljevo experienced demonstrations in which about 100,000 people participated; in Vranje, about 150,000 protesters demonstrated; in Leskovac and Kragujevac, the participation achieved about 200,000

5 ZACHARIAS, 210.

6 Vidoslav STEVANOVIĆ, Milošević. The People's Tyrant, London 2004, 35.

7 Jasna DRAGOVIĆ-SOSO, Spasionici nacije. Intelektualna opozicija Srbije i oživljavanje nacionalizma, Beograd 2004, 310.

8 Slobodan ANTONIĆ, Zarobljena zemlja. Srbija za vlade Slobodana Miloševića, Beograd 2002, 411.

9 Sabrina RAMET, Nationalism and Federalism in Yugoslavia, 1962-1991, Indianapolis 1992, 231. 
people, and the strongest protests took place in Niš, southern Serbia, where about 300,000 people joined in the protests. ${ }^{10}$

From the beginning of July to 6 October Milošević' supporters organized 32 such protests in 28 towns of Vojvodina. ${ }^{11}$ According to the estimates more than 575,000 people, i.e. about $28 \%$ of population of Vojvodina were involved in the protests in that autonomous province. ${ }^{12}$ On 5 October 100,000 gathered in Novi Sad. ${ }^{13}$ After the meeting, the party and autonomous leaders of Vojvodina decided to bow to the pressure of the demonstrators, and the top representatives of Vojvodina resigned. Under the pressure of similar meetings, the party and republic leaders in Montenegro also resigned on 11 November 1989. ${ }^{14}$

Until 19 November 1988, Slobodan Milošević did not participate in person in the meetings of truth. ${ }^{15}$ Direct participation in the meetings could provoke, particularly in the initial period of appearance of the meetings, sharp responses of the other representatives of individual Yugoslav leagues of communists and it would show too clearly that change of power relations in Yugoslavia was attempted by mobilization of the population. At the first meeting where Slobodan Milošević appeared in Belgrade had a participation of about $1,000,000$ protesters. Louis Sell states that that meeting showed that Slobodan Milošević was able to appeal to a big part of the society. Additionally to militant Kosovo Serbs who had arrived in national costumes, also relatively large numbers of young people, workers or intellectuals participated in the meeting. ${ }^{16}$ The Belgrade opposition supported the meetings. Some opposition circles founded associations to support the organization of the meetings. Dobrica Ćosić, an influential representative of opposition, saw the "beginning of mass democratic movement" 17 in them Milošević won "not only groups of poorer population and a considerable part of the intelligence - even several members of the Praxis group - but also the league leaders scared by his combative policy." 18

The alliance with the demonstrators during the Anti-bureaucratic revolution created the impression of mass support to Slobodan Milošević person and political course across the whole society. According to Slobodan Antonić, a Belgrade sociologist, "Milošević completed the revolution in that manner in 1988 in the legitimization way of that time. He did not derive the charisma from the party any more, like the other communist leaders who were popular like the party leaders and did not become party leaders because they were popular." 19 Milošević succeeded in getting support also of lower positioned members of the communist party who were very often involved in the organization of the meetings of truth. Within the Socialist League of Workers of Serbia that was under control of the Lea-

10 ANTONIĆ, Zarobljena zemlja, 93.

11 Emil KERENJI, Vojvodina since 1988, in: Serbia since 1989. Politics and Society under Milošević and after, Sabrina P. RAMET - Vjeran PAVLAKOVIĆ (eds.), Washington 2007, 352.

12 COHEN, Serpent in Bosom, 75.

13 Sabrina RAMET, The Three Yugoslavias. State-Building and Legitimation, 1918-2005, Washington $2006,352$.

14 RAMET, The Three Yugoslavias, 353.

15 SELL, 62.

16 Ibidem.

17 PIRJEVEC, 452.

18 Ibidem, 453.

19 ANTONIĆ, Zarobljena zemlja, 95. 
gue of Communists of Serbia, local communists very often helped to organize the workers' protests.

The media constituted a very essential ally to Milošević. After assuming power in 1987, he pushed through his closest collaborators to the most influential Serbian media. ${ }^{20}$ Except for Borba, the party press of the LCY, Milošević' Anti-bureaucratic revolution was supported by all important Serbian media. ${ }^{21}$ The most significant daily newspapers under Milošević' control involved Politika and Politika ekspres, the Duga and NIN weekly magazines..2 Also his supporter Dušan Mitević, director of Radiotelevision of Serbia, the most important Serbian TV and radio, tried to present a positive media picture of the president of the Serbian communists. ${ }^{23}$ Milošević cultivated a relatively strong personality cult through the media too. ${ }^{24}$ That strategy was aimed to create the impression of general social popularity of Slobodan Milošević who often pointed out his political victories over his opponents, presenting them as crushing, even if they often were not so. Also at the time of the eliminating of Dragiša Pavlović, Milošević tried to create the impression of such victory over his opponent. The voting in the Central Committee of the LCS resulted in 11:5 then, with further four representatives abstaining from voting: ${ }^{25}$ nevertheless, the victory over Dragiša Pavlović was presented as a display of strong party support to Slobodan Milošević. In order to intensify the impression, numerous Milošević' supporters were invited to the session of the 8th CC of LCS.

To increase his popularity, Milošević used appropriately an important event consisting in ceremonial meeting at the occasion of the $600^{\text {th }}$ anniversary of the battle of Kosovo. The actual meeting was held on 28 June 1989 and was formally presided by the patriarch of the Serbian Orthodox Church. ${ }^{26}$ During the anniversary, improved relations between the League of Communists of Serbia and the Serbian Orthodox Church could be observed. ${ }^{27}$ Although the actual $600^{\text {th }}$ anniversary of the battle of Kosovo gave Milošević the opportunity to speak in front of 500,000 participants in Gazimestan exclusively about his political successes and improved position of Serbia in Yugoslavia and to deal with national myths and symbols, he also devoted some words to the promise of improving of the economic situation. So the speech given by Slobodan Milošević in Gazimestan included both elements: nationalism and promise of future economic development of Serbia. ${ }^{28}$

Great Milošević' popularity and big social hopes pinned on him by different currents of the Serbian society were evidenced also by the fact that until 1990, there was no significant opposition current criticizing him and finding greater social response. That results from the fact that Slobodan Milošević adapted substantially to social demands and changes,

20 Siniša MALEŠEVIĆ, Ideology, legitimacy and the new state, London 2002, 183.

21 STEVANOVIĆ, 35.

22 RAMET, The Three Yugoslavias, 345.

23 MALEŠEVIĆ, 173.

24 RAMET, The Three Yugoslavias, 346.

25 SELL, 48.

26 Volfgang PETRIĆ - Robert PIHLER, Drugi put u rat. Kosovo i medjunarodna zajednica, 1989-1999. Beograd $2002,44$.

27 Ibidem.

28 THOMAS, 50. 
accepted them, but did not allow them in any case to endanger the power monopoly of the League of Communists of Serbia significantly.

\section{Responses to opposition demands}

The representatives of opposition groups constitute important actors who interact with the governing elites during the transition. The governing party must be able to communicate with the opposition groups. Also the strength and intensity of protests constituted an appreciable factor, which was able to influence the governing elites on what level bow to social demands. ${ }^{29}$ Valerie Bunce states in this context that nationalistic protests arising before the disintegration of the regime often led to delayed establishment of democracy, while protests oriented against the existing regime and missing such charge and appearing at the same time in the process of disintegration of the regime were rather related to successful democratization. ${ }^{30}$

In the course of the Anti-bureaucratic revolution, Milošević got much broader support than only party support. The Serbian communists tried to win a part of the opposition. During already the meetings of truth, the Serbian communists and nationalists merged to some degree, as a part of the national opposition supported the meetings, participating in their organization. In that period, Milošević was supported even by a part of philosophers of non-orthodox Marxist current, members of the Praxis group, who promoted revision of the political system of Yugoslavia and who were attracted by the fight, proclaimed by Serbian communists, against bureaucratic elites and deformations of the political arrangement, caused by those elites. Mihailo Marković became one of the best known Milošević' supporters. ${ }^{31}$ The combination of socialism and Serbian nationalism also ensured support of the nationalist opposition that could act more freely. ${ }^{32}$ The Serbian censorship also allowed printing of nationalist publications. ${ }^{33}$ Some opposition intellectuals could publish more freely, without fearing stricter sanction by the League of Communists of Serbia. For example Milovan Djilas, a former member of the League of Communists of Yugoslavia, could publish again his opinions on the Yugoslav society. That step made the impression on the opposition that Serbia was freer under the guidance of Slobodan Milošević than it was during the guidance of Ivan Stambolić. Milošević probably counted upon future stronger support of the members of the Serbian Academy of Sciences and Arts (SANU), ${ }^{34}$ authors of the SANU Memorandum, a document criticizing the position of the Serbian nation and of Serbia in Yugoslavia, with strong anti-communist accent involved. But at the beginning, his contacts with the members of the Serbian Academy of Sciences and Arts were not too great, as they could have provoked strong anti-reactions of the communists of the other republics and autonomous provinces. But he won the support to his policy from influential members of SANU and from numerous authors of the Memorandum. ${ }^{35}$

\footnotetext{
29 BUNCE, 172.

30 Ibidem, 177.

31 COHEN, Serpent in Bosom, 86.

32 lbidem, 86-87.

33 RAMET, The Three Yugoslavias, 345.

34 COHEN, Serpent in Bosom, 86.

35 MALEŠEVIĆ, 181.
} 
The combination of most social demands could explain why in 1990, when the first plurality election was held, there was not any strong and successful anti-communist, anti-Milošević formation which was able to compete with the SPS. The legitimacy of the LCY, gradually lost by the communists in other parts of Yugoslavia, was very strong in Serbia and Montenegro. The party definitely did not avoid certain ideological changes, but it preserved its essential features.

\section{Degree of dependence on federal authorities and on other Leagues of Communists}

The specific conditions of the Socialist Federal Republic of Yugoslavia included one more condition - the degree of dependence on the other leagues of communists and, above all, the degree of dependence on the federal authorities. Such dependence can be reflected very strongly in the policy of those parties. The connection to voters in parties that are strongly dependent on other parties is problematic because such parties must harmonize different interests that often can be contradictory. Such parties must consider those interests in own strategy, and it is therefore difficult for them to formulate their own policy and to appeal to the voters. To strong manoeuvring between satisfaction of the interests of voters and of other subjects, such parties can become untrustworthy, which can be reflected in their society-wide support. The League of Communists of Serbia, before dominating the League of Communists of Vojvodina and Kosovo, was strongly dependent on the federation. It often got into conflicts with the representatives of both autonomous provinces and federal authorities, and the presidency of the League of Communists of Yugoslavia became the arbitrator of such conflicts. The Slovenian and Croatian communists, as representatives of the two most advanced republics, tried to push through the reforms performed at federal level, that were perceived as indispensable by local communist elites. The Slovenian and Croatian communists also supported the reformatory efforts of Ante Marković, the prime minister. But after the first election that the communists, ruling until then, lost, ending up in opposition in those republics, the support to the steps of the Yugoslav prime minister was not so high any more. ${ }^{36}$ The Serbian communists held a similar position and they did not wish interventions of the federal government into the competences of the Republic of Serbia either. On the other hand, the less developed republics, depending also on the Fund for the Underdeveloped Regions, particularly Bosnia and Herzegovina and Macedonia were strongly dependent on the federal government. For that reason, they did not wish bigger confrontation and they finally supported the reforms of the federal prime minister. That is why both transforming post-communist formations waived the self-management socialism to substantial degree in their political programs before the first plurality election, promising in economic issues to promote the introduction of market economy. Montenegro and Kosovo, also constituting parts of Yugoslavia drawing assistance from the Fund for the Underdeveloped, were politically dependent on the leaders of the Serbian Communists; therefore they were forced to copy Slobodan Milošević' policy. The conflicts

36 Mladen LAZIĆ - Laslo SEKELJ, Privatisation in Yugoslavia (Serbia and Montenegro). in: Europe-Asia Studies $49,1997,6,1058$ 
between Slovenia, Croatia and Serbia finally resulted in refusal of the leaders of the two most developed republics to contribute to the less developed parts of Yugoslavia.

As Slobodan Antonić states, Ante Marković represented a strong alternative. According to the Serbian sociologist, the popular Ante Marković could endanger the leading position of the Serbian communists. After the disintegration of the League of Communists of Yugoslavia, he declared that "further running of Yugoslavia did not depend on the LCY." 37 The federal government tried to play a bigger role in the federation, but its position was devaluated by the independent development by some Yugoslav republics. It promoted the reforms very actively, but its steps were spoiled by the more developed republics that promoted independently their own economic policy. Before the elections the government of the Republic of Serbia also decided to take 28 billion dinars from the federal bank of Yugoslavia to use them for covering the financial losses of Serbian companies and to pay out the employees' wages. Such strategy strongly damaged the intentions of the federal government, not only because the consistent austerity measures and fight against inflation was complicated by that, but also because Slovenia and Croatia from that moment refused to recognize the federal debts. Due to that step, the federal government lost $15 \%$ of its existing budget and was forced to operate in restricted form. ${ }^{38}$ Ante Markovićs reforms constitute transition to market economy and strategy of shock therapy that had already been announced in December 1989. In that regard, two concepts of solution of economic problems of the country clashed on the territory of Serbia. On one hand the concept of federal prime minister Ante Marković and on the other hand the leaders of the Serbian communists. Slobodan Milošević tried to forestall Ante Marković's plans that would lead to economic problems of Serbia in connection with transition to market economy. In most post-communist countries, the frustration related to shock therapy and to transition of the economic model led to the support of former communist parties. In Serbia, those strategies clashed at the same moment, and the leaders of the League of Communists of Serbia decided to guarantee the benefits of the existing economic system, fearing that the reforms could endanger the support of the economically weaker group of voters of the Socialist Party of Serbia.

\section{SPS strategy before the elections 1990}

On 15 December 1989, at the 11th Congress of the League of Communists of Serbia, under pressure of the events taking place in the other parts of Yugoslavia, the Serbian communists decided to give up their political monopoly and to introduce political pluralism. ${ }^{39}$ The LCS took over a part of the opposition demands and used them to its own benefit. ${ }^{40}$ Slobodan Milošević was not defender of the plurality political system; he

37 ŠTĚPÁNEK, 423.

38 RAMET, Balkan Babel, 55.

39 Diana VUKOMANOVIĆ, A Short History of Political Parties, in: Elections to the Federal and Republican Parliaments of Yugoslavia (Serbia and Montenegro) 1990-1996. Analyses. Documents and Data, Vladimir GOATI (ed.), Berlin 1998, 35.

40 Zoran SLAVUJEVIĆ, The Issues: Dimension of Electoral Confrontations, in: Elections to the Federal and Republican Parliaments of Yugoslavia (Serbia and Montenegro) 1990-1996. Analyses. Documents and Data, Vladimir GOATI (ed.), Berlin 1998, 87. 
preferred the existing political system, but after the changes in Central and Eastern Europe as well as in the other Yugoslav republics, he decided to bow to the social demands in this regard. ${ }^{41}$ According to Slobodan Samardžić, those changes took place in Serbia after the Serbian communists became aware that they would be able to hold the dominant position even in a modified political environment. ${ }^{42}$ Serbia also experienced protests asking for introduction of plurality system, but such demands were relatively week. The newly emerging political parties and groups in Serbia were not able to specialize, to build a membership and to create tools of communication between their own members and the public. ${ }^{43}$ On 16 and 17 June 1990, the Unification Congress of the League of Communists of Serbia and the Socialist League of Workers of Serbia was held to create the common Socialist Party of Serbia. Thanks to that union, the Serbian communists were able to face the outflow of party members, as it was stated above. But the merger constituted another benefit consisting in the possessions of the Socialist League of Workers of Serbia, estimated at about 160 million USD. ${ }^{44}$ The League of Communists was formally dissolved. ${ }^{45}$

Gradually, three significant opposition parties were established within the political system, additionally political parties representing the interests of the ethnic minorities within Serbia. The parties were: the Serbian Renewal Movement, the Serbian Radical Party and the Democratic Party. The leaders of the three parties had strong nationalistic orientation ${ }^{46}$ The $^{2}$ Democratic League of Kosovo (DLK) became the most significant party representing the interests of the Kosovo Albanians. The party was established on 23 December 1989, and Ibrahim Rugova, a writer, was elected to lead it. In less than two months, about 200,000 Kosovo Albanians joined DLK. ${ }^{47}$ In several months, up to 300,000 members joined that political party; ${ }^{48}$ such number constitutes approximately triple the former membership of the League of Communists of Kosovo.

Zoran Slavujević points out the general weakness of individual opposition groups active by the end of the 1980s. "Their public activities were disorganized and their views barely articulated. The ruling party, the only organized political force, turned to its own benefit by taking over the opposition's ideas and imposing itself as the leader of the national movement." " 49 The forming Serbian opposition constituted rather a weaker actor who was not able to force the governing SPS to negotiations, which strengthened considerably the position of this party. The Democratic League of Kosovo, declaring boycott against Serbian and Yugoslav institutions, constituted an exception in this regard. The party even refused to participate in the election in 1990.

Although Serbia had already experienced a strong wave of protests in 1988, the leaders of

41 Gregory HALL, The Politics of Autocracy: Serbia under Slobodan Milošević, in: East European Quarterly 33, $1999,2,238$.

42 Ibidem.

43 SLAVUJEVIĆ, 87.

44 THOMAS, 63.

45 COHEN, Serpent in Bosom, 119.

$46 \mathrm{HALL}, 242$.

47 Ibidem.

48 Jan PELIKÁN, Národnostní otázka ve Svazové republice Jugoslávii. Geneze-vývoj-perspektivy, Praha 1997, 37. 49 SLAVUJEVIĆ, 87. 
the League of Communists of Serbia used them for their favour to strengthen their position all over the Republic of Serbia. The party also preserved considerable advantages consisting, according to John Ishiyama, in its history and firm institutional structure, inherited by the post-communist parties from their predecessors, unlike the newly created opposition subjects. ${ }^{50}$ Slobodan Antonić evaluates the attitudes of the leaders of the Serbian communists towards the social demands asking for political changes as very lax and adds that "Although the process of disintegration of socialist regimes and restoration of parliament practice in Eastern Europe - in Slovenia and Croatia - has advanced already, the opportunities in Serbia showed weak tendency of falling behind in this social trend. Carried on the wave of inertia of the Anti-bureaucratic revolution from 1988 that provided sufficient national legitimacy to power, the governing elites in Serbia did not meet the more and more vociferous demands on party pluralization of political life, offering instead of it the formula of so called non-party pluralism... that was expected to protect the results of historical unification of the Serbian nation around their leaders. "51 The development in the other parts of Yugoslavia forced the unwilling Serbian communists to perform partial changes. With the promise of a new political system, the Serbian constitution was changed again, in September 1990, i.e. three months before the planned election. ${ }^{52}$ Serbia fell behind the other republics of Yugoslavia. The draft new constitution was unambiguously subordinated to the needs of the Serbian post-communists. But all political parties had only very little time left until the election, and the election was performed according to the rules dictated by the ruling SPS. ${ }^{33}$ The ruling party pushed through, without participation of the opposition parties, the two-round majority system for the forthcoming elections, wishing to confirm its superiority with its help. The opposition parties did not agree with the application of the majority system for the forthcoming elections; they asked the ruling SPS to introduce proportional election system; but, after some hesitation, they finally decided to participate in the forthcoming election. ${ }^{54}$ The forming opposition had no space to formulate its preferences, and its demands were not considered. The Serbian opposition was fragmented and stood completely at the margin of the political development.

The parliamentary election was called for December 1990. SPS recorded crushing victory in the election; the general election turnout was weaker in Serbia in comparison with the other republics. In Serbia, about $71.5 \%$ voters participated in the election, while the election turnout in the neighbouring Bosnia and Herzegovina oscillated around $77 \%$ and exceeded $80 \%$ in all other republics. ${ }^{55}$ One of the reasons of lower election turnout as compared to the other republics consists in the attitude of most inhabitants of Kosovo where the election turnout was very low due to the boycott of the Kosovo Albanians. Without including

50 ISHIYAMA, 845.

51 Slobodan ANTONIĆ, Srbija izmedju populizma i demokratije. Politički procesi u Srbiji 1990-1993, Beograd 1993, 4-5.

52 HALL, 240.

53 ANTONIĆ, Srbija izmedju populizma i demokratije, 9.

54 Milan JOVANOVIĆ, Izborni sistem Srbije - dve decenije posle, in: Partije i izbori u Srbiji - 20 godina, Slaviša ORLOVIĆ (ed.), Beograd 2011, 237.

55 Vladimir GOATI, Jugoslavija na prekretnici, in: Jugoslavija na prekretnici . Od monizma do gradjanskog rata, Vladimir GOATI (ed.), Beograd 1991, 27-28. 
Kosovo, the election turnout in Serbia oscillated about $76 \%$ in 1990.56 In the two-round parliamentary election held on 9 and 26 December 1990, the SPS won 45.8\% votes and the majority election system allotted 190 mandates to it in the Serbian National Assembly with 250 members, which corresponded to approximately $78 \%$ of all mandates. ${ }^{57}$ Now the office of Serbian president was subject to direct election too; in November 1990, Slobodan Milošević already defended his mandate in the first round, getting $65.35 \%$ votes. ${ }^{58}$

\section{Conclusion}

The post-communist parties, making use of all advantages of their organizational structure in their strategy aimed at handing on to power, corresponding the best to Kitschelt's model of a clientelistic party. The party systems of clientelistic and charismatic parties can last under two conditions: if they "1) deal with unsophisticated, uneducated voters for whom the discrepancy between democratic rules and party performance is not noticeable or problematic and 2) they do not operate in the environment of economic growth and sectoral change that upsets the balance of political coalitions crafted by such party systems. " ${ }^{59}$ The second point is related to the growth of a stable middle class that, according to Kitschelt, prefers "progressive movements against clientelistic parties." 60 The organizational structure played a very important role because the ruling SPS strived to preserve the bonds with the groups that had traditionally supported the League of Communists of Yugoslavia. Its structure corresponds to Kitschelt's model of cartel party, and those bonds allowed the party to preserve its former power in changing conditions. The strong organizational structure of the SPS and the connection to the elites of Serbia allowed the party also to overcome several crises experienced by the semi-authoritative regime in later periods of its existence. Three essential factors helped SPS to hand on to power. The first consisted in the response of the League of Communists of Serbia, or of the Socialist Party of Serbia, to the economic crisis. It is not about the direct factor of the economic crisis but about the strategy chosen by the ruling political party. SPS made use of the inhabitants' fear from the changes pushed through by the federal government. The second factor consisted in general weakness of federal institutions when pushing through their policy for which they needed the consent of the republics very frequently. The third factor consisted in the strong position and stability of the LCS and in the relatively easy transformation into the Socialist Party of Serbia. The leaders of that political party were unified from 1987. The inner opposition in the party was significantly reduced by the intensity and frequency of the party purges. The League of Communists of Croatia and, above all, the League of Communists of Serbia constituted the parties in which the party purges were the most intensive during Tito's era. The League of Communists of Serbia represented a political party in which intensive party purges took place also in connection with Slobodan Milošević's successful

\footnotetext{
56 Ibidem, 28.

57 OBRADOVIĆ, 428.

58 Ibidem.

59 KITSCHELT, 450.

60 Ibidem.
} 
attempt to gain control over Serbia after 1987. Between 1988 and 1989, party purges took place in Vojvodina and Kosovo as well. Those steps reduced the probability of establishing of an influential internal opposition in the party. The extensive party purges strengthened the party especially before the Serbian society entered to transition. The position and stability of a political party is represented by the number of its members and by recruitment of new members from people with neutral political orientation or directly from the opposition. All such factors have impact on the transforming potential of the ruling party, without considerable internal splitting of the party. The Serbian communists were successful in their effort to recruit new members and to reduce the negative impacts of considerable outflow of former LCS members, and they were able to preserve the existing party infrastructure. The League of Communists of Kosovo constituted the only exception in this regard; it experienced mass outflow of members from among Kosovo Albanians after strong restriction of the autonomous status of Kosovo. So the SPS was able to preserve distinctive superiority against the newly formed political parties.

\section{Abstract}

The main aim of the article is to explain the advantages of organizational structure of the League of Communists of Serbia, which enabled the party to remain in power after the Serbian elections in 1990. The article focuses on several factors which strengthened the central leadership of the Serbian communist party, such as the completed process of generational changes, intensive and frequent party purges, the decrease of party membership and the party's ability to recruit new members, ethnic homogeneity among party members, the reaction of party leaders to the demands of Serbian opposition, charismatic leaders and the level of dependence on the federal authorities and the other Leagues of communists. Although the article focuses mainly on the transformation of the League of Communists of Serbia, it also deals with the party organizations of other republics and autonomous provinces as well as the party's army organization of the League of Communists of Yugoslav People's Army, which was also member of the League of Communists of Yugoslavia. After adopting the new constitution in 1974 the republics and autonomous provinces became even more independent on the federal institutions, and even the differences among the communists during the 1980s, after the death of Tito, arose, which affected further political development of Yugoslavia.

\section{Keywords}

Yugoslavia, Serbia, Vojvodina, Kosovo, communism, transition, League of Communists of Serbia, League of Communists of Yugoslavia 